\title{
No place to hide
}

Hassan, L.M.; Shiu, E.M.

\section{Tobacco Control}

\author{
DOI: \\ 10.1136/tobaccocontrol-2013-051238
}

Published: 01/03/2015

Peer reviewed version

Cyswllt i'r cyhoeddiad / Link to publication

Dyfyniad o'r fersiwn a gyhoeddwyd / Citation for published version (APA):

Hassan, L. M., \& Shiu, E. M. (2015). No place to hide: two pilot studies assessing the effectiveness of adding a health warning to the cigarette stick. Tobacco Control, 24(e1), e3-e5. https://doi.org/10.1136/tobaccocontrol-2013-051238

\footnotetext{
Hawliau Cyffredinol / General rights

Copyright and moral rights for the publications made accessible in the public portal are retained by the authors and/or other copyright owners and it is a condition of accessing publications that users recognise and abide by the legal requirements associated with these rights.

- Users may download and print one copy of any publication from the public portal for the purpose of private study or research.

- You may not further distribute the material or use it for any profit-making activity or commercial gain

- You may freely distribute the URL identifying the publication in the public portal ?

Take down policy

Copyright $@ 2015$ by the BMJ Publishing Group Ltd

Take down policy

If you believe that this document breaches copyright please contact us providing details, and we will remove access to the work immediately and investigate your claim.
} 
USING THE CIGARETTE STICK FOR PUBLIC HEALTH WARNINGS

No place to hide: Two pilot studies assessing the effectiveness of adding a health warning to the cigarette stick

Louise M, Hassan, PhD, Bangor University and Edward Shiu, MSc, Bangor University

Louise M. Hassan, Bangor Business School, Bangor University, Bangor LL57 2DG, Phone +44 1248 382161, FAX None, e-mail: 1.hassan@ bangor.ac.uk.

Edward Shiu, Bangor Business School, Bangor University, Bangor LL57 2DG, e-mail: e.shiu@bangor.ac.uk.

Keywords: smoking, prevention, tobacco, product labelling, on-stick warning Word count: 1,548 


\section{USING THE CIGARETTE STICK FOR PUBLIC HEALTH WARNINGS}

\section{Abstract}

Objective To examine whether health warnings printed onto the cigarette stick would increase intentions to quit.

Methods Two experiments with smokers were conducted. The first study was conducted in Scotland on 88 adult (aged 18 or over) smokers recruited around two university campuses. The second study was conducted on 120 adult (aged 16 or over) smokers recruited around inner city cafes in Greece. Study 1 tested smokers' ratings of the attractiveness of cigarettes printed with either 'minutes of life lost' (minute condition) or 'toxic constituents' (toxic condition) against a control cigarette as well as the change in participants' pre and post exposure quitting intentions. Study 2 only assessed the effect of the minute condition on smokers' change in quitting intentions. Analysis of variance and paired-samples t-tests were undertaken. Participants in Study 1 were shown a picture of the stimuli, with participants in Study 2 given the actual cigarette to hold.

Results The analyses revealed increases in quitting intentions post exposure for the minute condition (mean paired difference $=0.68, P<0.001)$ and the toxic condition (mean paired difference $=0.23, P<0.05)$ in Study 1. Similar findings were found for the minute condition (mean paired difference $=0.38, P<0.001$ ) in Study 2 .

Conclusions These results suggest that printing a public health warning on the cigarette stick may result in higher intentions to quit smoking. However, many other messages (e.g., benefits of quitting, harmful effects of secondhand smoke) which can be printed on the cigarette stick have not been tested in the current studies.

Keywords: smoking, prevention, tobacco, product labelling, on-stick warning 


\section{USING THE CIGARETTE STICK FOR PUBLIC HEALTH WARNINGS}

\section{INTRODUCTION}

Although substantial research has explored the impact of communication efforts on smokers, for example the effectiveness of warning labels ${ }^{1}$ and anti-tobacco advertising ${ }^{2}$, one area that lacks research is the potential effect of using the product as a public health message. Packaging is extensively used as a means of communicating the risks of smoking with most countries mandating that warnings be displayed on the pack. Canada also mandates the inclusion of inserts requiring a warning and information message inserted within the cigarette pack. However, the product (cigarette) itself contains no warnings. Other consumer goods such as children's toys and household electrical goods carry warnings both on the packaging and on the products themselves. Tobacco research found that when graphic warnings were introduced, $36 \%$ of smokers attempted to avoid the warnings including (21\%) using a different case for their cigarettes. ${ }^{3}$ However, avoidance is not necessarily associated with lower likelihood of quitting particularly over a longer time frame. ${ }^{4}$ Research has also showed many people purchasing and smoking 'single' cigarettes with these smokers less likely to be exposed to on-pack warnings. ${ }^{5}$ Despite bans on the sale of single cigarettes, this practice is still prevalent. ${ }^{6}$ The above discussion evidences the need to look beyond using the pack as the sole product-related means of providing smokers with information about the dangers of smoking. The present paper makes a contribution to the literature by investigating whether or not printing public health warnings on the cigarette stick would lead to increased intentions to quit. This research is timely given findings showing the potential negative influences of branded sticks which might be adopted by the tobacco industry. ${ }^{7}$

\section{METHODS}

\section{Study 1}

To explore the potential impact of including a health warning on the cigarette stick, a scenario-based field experiment with 88 current smokers was conducted. The data collection 


\section{USING THE CIGARETTE STICK FOR PUBLIC HEALTH WARNINGS}

was undertaken around two inner city university campuses within Scotland. Around one third of the sample (35\%) were aged 18-21 while $44 \%$ were aged $22-25,7 \%$ were aged $26-29$ and $14 \%$ were aged 30 years or over. Females represented over half of the respondents (61\%).

Each smoker saw an identically framed colour photograph (see figure 1) of an unlit cigarette balanced on an empty clear glass ash tray. The photograph of the cigarette was embedded within the questionnaire. An A5 size photograph was used to ensure that respondents could clearly visualise the warning. No brand information was displayed. Smokers were randomly assigned into one of three conditions with 24 smokers assigned to the control condition where they saw a photograph of a standard cigarette which was white with a cork coloured cigarette filter (the filter remained unaltered in all conditions). Thirty four smokers saw a cigarette which was printed with the following warning "Each puff reduces your life expectancy by ...” together with graphics showing 11 minute time lines (1 to 11 minutes) progressing down the length of the cigarette (minute condition). Thirty smokers saw a cigarette with (five) words of toxic constituents (arsenic, benzene, formaldehyde, pesticides, tar) printed on it (toxic condition).

Prior to the smokers seeing the photograph, demographic information was solicited and quitting intentions measured using: "Your intention to stop smoking is..." ( $0=$ "not at all" to $6=$ "very strong"). After viewing the photograph the smokers were asked the attractiveness of the cigarette ("The cigarette is") with 4-items (attractive, classy, pleasant, and appealing) each on a 7-point semantic differential scale $(0=$ "not attractive/classy/pleasant/appealing" to 6="attractive/classy/pleasant/appealing"). The four items were aggregated to form an overall measure of attractiveness (Cronbach's alpha $=0.90$ ). Pre and post exposure quitting intentions were assessed using the same measure.

\section{Study 2}




\section{USING THE CIGARETTE STICK FOR PUBLIC HEALTH WARNINGS}

A before and after exposure experiment without control was undertaken on 120 smokers in cafes around the city centre in Athens, Greece. Just under half of the sample (47\%) were aged 16-25 with 33\% aged 26-35, and 20\% aged over 35 years. Males represented over half of the respondents $(60 \%)$.

After eliciting the smokers' pre exposure quitting intentions, participants were allowed to see and hold the stimulus (cigarette with a minute condition printed) until at the end of the interview. The pre and post intentions were each measured with three items ("I intend/plan/expect to quit smoking"), with responses $0=$ "very unlikely" to $6=$ "very likely". Filler questions were inserted between the measures of the pre and post quitting intentions to disguise the purpose of the study.

\section{Statistical analysis}

Non-parametric and parametric tests were used, including chi-square test, analysis of variance (ANOVA), repeated measures ANOVA and paired-samples t-tests. The analyses were conducted using SPSS 18.0 for windows.

\section{RESULTS}

\section{Study 1}

To ensure that the samples were similar in demographic characteristics (age and gender) across the conditions, chi-square tests were conducted. The results showed no bias in gender (chi-square $=0.16, P=0.93$ ) or age (chi-square $=6.53, P=0.37$ ) representation. It was anticipated that when compared against the control condition, the attractiveness ratings for the cigarette in the two experimental conditions would be lower. Significant differences were found across the three conditions, (see table $1, P<0.001$ ), with the follow-up Scheffe test showing the minute and toxic conditions $\left(P^{\prime} s^{<}<0.05\right)$ to be significantly different from the control 


\section{USING THE CIGARETTE STICK FOR PUBLIC HEALTH WARNINGS}

condition. No significant difference was found between the minute and toxic conditions $(P=0.95)$.

To provide an indication of the potential change in behaviour that might arise as a result of the on-stick warnings, a repeated measures ANOVA was undertaken to assess if any changes in quitting intentions, pre and post exposure to the stimuli, were apparent. It was expected that a significant increase in quitting intentions post against pre exposure would occur in the experimental conditions but not in the control condition. Examining the change in quitting intentions revealed a significant increase in quitting intentions post exposure $(P<0.001)$, and a significant interaction between exposure and condition $(P<0.05)$. Followup paired-samples $t$-tests revealed no significant difference for the control condition $(P=0.083)$. However, significant differences were found for both the minute and toxic $\left(P^{\prime} s^{<0.05)}\right.$ conditions with increases in quitting intentions found post exposure. Taken together, these results indicate the potential to increase smokers' quitting intentions with an on-stick warning. The results also showed a stronger effect on the change in quitting intentions for the minute condition (Cohen's $\mathrm{d}=0.65$ ) than for the toxic condition (Cohen's $\mathrm{d}=0.41$ ). Given that only the picture of a cigarette was shown to the subjects, one might question the degree of realism of the stimulus. To address this, a second study was undertaken exploring a minute condition given the stronger effect found.

\section{Study 2}

Study 2 aims to validate the significant effect of a minute condition on the change in smokers' quitting intentions pre and post exposure found in Study 1. The purpose was to demonstrate that a similar effect will be realised with a physical stimulus rather than with a photograph. A paired-samples t-test showed a significant (see Table $1, P<0.001$ ) increase in quitting intentions after exposure to the actual cigarette thus the finding of Study 1 was corroborated. 
USING THE CIGARETTE STICK FOR PUBLIC HEALTH WARNINGS

Table 1 Study 1 and Study 2 results

\begin{tabular}{|c|c|c|c|c|c|}
\hline & Attractiveness & Quitting intentions & & & \\
\hline & Mean post $(95 \% \mathrm{CI})$ & Mean pre $(95 \% \mathrm{CI})$ & Mean post $(95 \% \mathrm{Cl})$ & $\begin{array}{l}\text { Mean paired (post - pre) } \\
\text { difference }(95 \% \mathrm{Cl})\end{array}$ & $t(P$-value) \\
\hline Study 2: Minute & & 2.44 & 2.83 & $0.38(0.23$ to 0.54$)$ & $4.90(<0.001) \S$ \\
\hline Study 1: Minute & $1.17(0.79$ to 1.55$) *$ & $3.26(2.62$ to 3.91$) \dagger$ & 3.94 (3.35 to 4.53$) \ddagger$ & $0.68(0.32$ to 1.04$)$ & $3.81(<0.001) \S$ \\
\hline Study 1: Toxic & $1.26(0.79$ to 1.73$)$ * & $3.83(3.16$ to 4.51$) \dagger$ & 4.07 (3.44 to 4.69$) \ddagger$ & $0.23(0.02$ to 0.45$)$ & $2.25(0.032) \S$ \\
\hline Study 1: Control & $2.36(1.94$ to 2.79$)$ * & $3.00(2.10$ to 3.90$) \dagger$ & $3.13(2.23$ to 4.02$) \ddagger$ & $0.13(0.02$ to 0.27$)$ & $1.81(0.083) \S$ \\
\hline
\end{tabular}

* ANOVA comparing mean post exposure attractiveness across minute/toxic/control conditions $F=9.16(P$-value $<0.001)$. † ANOVA comparing mean pre exposure quitting intentions across minute/toxic/control conditions $F=1.38(P$-value=0.258). $\ddagger$ ANOVA comparing mean post exposure quitting intentions across minute/toxic/control conditions $F=2.08(P$-value=0.131). $\S t$ and $P$ values assessing change (post - pre) in quitting intentions using paired-samples t-test.

$\mathrm{Cl}$, confidence interval; scale ranges from 0 to 6 with 6 indicating higher quitting intentions/attractiveness; attractiveness is an aggregation of four items; quitting intentions is an aggregation of three items in Study 2. 


\section{USING THE CIGARETTE STICK FOR PUBLIC HEALTH WARNINGS}

\section{DISCUSSION}

There is a lack of research on the effectiveness of on-product warnings with some research treating on-product and on-package warnings identically. ${ }^{8}$ Only one study contrasted inmanual versus on-product warnings in an IT context showing that on-product warning benefit compliance. ${ }^{9}$ Our study provides results which suggest that displaying health warnings on the cigarette stick may result in higher quitting intentions. Our finding in Study 1 regarding the relatively weaker effect of the toxic condition on quitting intentions needs to be contextualized. Past research has shown smokers in the UK to be less aware of the toxic constituents in cigarettes as well as to exhibit lower levels of knowledge regarding the harmful effects of such toxic constituents. ${ }^{1011}$ Therefore if toxic constituents were to be printed on the stick, in-pack inserts and/or advertising campaigns would be needed to enable the on-stick warning to be effective. ${ }^{12}$ Although this study provides initial findings on a topic which to date has not been widely discussed by tobacco control researchers, ${ }^{13}$ the study is limited in a number of ways.

Potential limitations of the study include self-selection bias in the sampling design and information bias arising from socially desirable responding. Further, participants were only shown test cigarettes but not packs with warnings, so our study cannot make claims regarding the additional effects of on-stick warnings over and above that derived from the warnings on the pack. A pertinent question not addressed is whether the on-stick warning might work better on smokers who avoid or dismiss the warnings on the pack. Lastly, our study has limitations in relations to internal and external validity. The lack of a control group in Study 2 poses a potential threat to internal validity and so the results of Study 2 should not be taken on its own merit but only as support for the results found in Study 1. The convenient samples recruited for our studies would not allow us to make claims as to the generalisability of our 


\section{USING THE CIGARETTE STICK FOR PUBLIC HEALTH WARNINGS}

findings to the wider population if on-stick warnings were to be adopted as government policy.

Future research should examine if a practical application of the minute condition would lead to smokers extinguishing the cigarette sooner. From a policy perspective, would it be legal and feasible to mandate tobacco companies to print health messages on cigarette sticks. Under plain packaging laws some researchers have already advocated that it would be. ${ }^{14}$

\section{What is already know on this topic}

Substantial knowledge has been gained on the role of warning labels on cigarette packages in influencing smokers yet using the cigarette stick itself has not received research attention in this regard.

\section{What this study adds}

- Public health warnings printed on the cigarette stick could increase smokers' intentions to quit.

- The largest mean change in quitting intentions occurred for cigarette sticks printed with a warning telling smokers of the life (amount of time) lost through smoking a single cigarette.

- Policy makers need to consider the possibilities of mandating cigarette warnings or other health messages printed on the cigarette stick as part of plain packaging or health warning legislations.

Acknowledgements The authors would like to thank Vanessa Jones and Elli Theodoraki for their assistance with the data collection for this research.

\section{Competing interests None.}

Ethics approval Prior to participation, the details of the research and ethical issues arising from participation were explained to potential participants (i.e., freedom to withdraw at any 


\section{USING THE CIGARETTE STICK FOR PUBLIC HEALTH WARNINGS}

time, only answer questions they wished, anonymity, and data reporting requirements). The questionnaire was administered only to those who agreed to take part.

Contributions LH: supervised the design and data collection as well as undertook the analysis and writing of the manuscript. ES: contributed to the data analysis and writing of the manuscript. Both authors contributed equally to the revision of the article and approved the final version of the manuscript.

Funding None.

\section{References}

1 Hammond D. Health warnings on tobacco packages: a review. Tob Control 2011;20:32737.

2 Shadel WG, Fryer CS, Tharp-Taylor S. Uncovering the most effective active ingredients of antismoking public service announcements: the role of actor and message characteristics. Nicotine Tob Res 2009;11:547-52.

3 Hammond D, Fong GT, McDonald PW, et al. Graphic Canadian cigarette warning labels and adverse outcomes: evidence from Canadian smokers. Am J Public Health 2004;94:1442-45.

4 Borland R, Yong $\mathrm{H}-\mathrm{H}$, Wilson $\mathrm{N}$, et al. How reactions to cigarette packet health warnings influence quitting: findings from the ITC Four-Country survey. Addiction 2009;104:66975.

5 Thrasher JF, Villalobos V, Barnoya J, et al. Consumption of single cigaretees and quitting behavior: a longitudinal analysis of Maxican smokers. BMC Public Health 2011;11:134.

6 de Ojeda A, Barnoya J, Thrasher JF. Availability and costs of single cigarettes in Guatemala. Nicotine Tob Res 2013;15:83-7.

7 Borland R, Savvas S. Effects of stick design features on perceptions of characteristics of cigarettes. Tob Control 2013;22:331-7. 


\section{USING THE CIGARETTE STICK FOR PUBLIC HEALTH WARNINGS}

8 Argo JJ, Main KJ. Meta-analyses of the effectiveness of warning labels. J Public Policy \& Marketing 2004; 23:193-208.

9 Smith JJ, Wogalter MS. Behavioral compliance to in-manual and on-product warnings. Proceedings of the Human Factors and Ergonomics Society 54 ${ }^{\text {th }}$ Annual Meeting 2010; 1846-50.

10 Hammond D, Fong GT, McNeill A, et al. Effectiveness of cigarette warning labels in informing smokers about the risks of smoking: findings from the International Tobacco Control (ITC) Four Country Survey. Tobacco Control 2006;15(suppl 3):iii19-25.

11 Siahpush M, McNeill A, Hammond D, et al. Socioeconomic and country variations in knowledge of health risks of tobacco smoking and toxic constituents of smoke: results from the 2002 International Tobacco Control (ITC) Four Country Survey. Tobacco Control 2006;15(suppl 3):iii65-70.

12 Thrasher JF, Murukutla N, Pérez-Hernández R, et al. Linking mass media campaigns to pictorial warning labels on cigarette packages: a cross-sectional study to evaluate effects among Mexican smokers. Tob Control 2013;22:e57-65.

13 Cunningham R. Gruesome photos on cigarette packages reduce tobacco use. Bull World Health Organ 2009;87:569.

14 Freeman B, Chapman S, Rimmer M. The case for the plain packaging of tobacco products. Reports on Industry Activity from Outside UCSF, Center for Tobacco Control Research and Education, UC San Francisco 2007. 